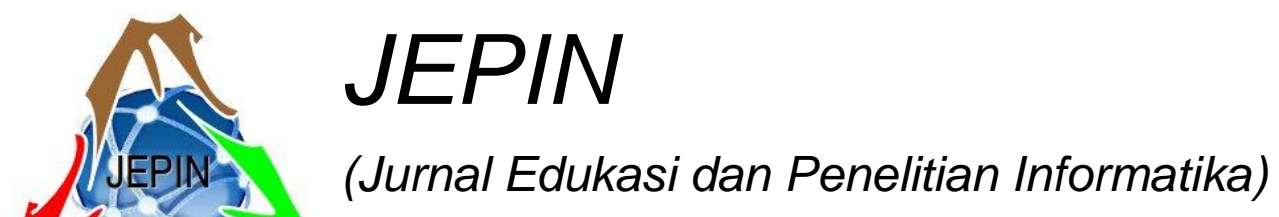

Vol. 6

No. 2

ISSN(e): 2548-9364 / ISSN(p) : 2460-0741

\title{
Model Penilaian Perangkat Lunak E-Government untuk Rekomendasi Pemeliharaan (Studi Kasus: BKPSDM Ketapang)
}

\author{
Rizqia Lestika Atimi ${ }^{\# 1}$, Novi Indah Pradasari ${ }^{\# 2}$ \\ \#Jurusan Teknik Informatika, Politeknik Negeri Ketapang \\ Jalan Rangga Sentap - Dalong, Kelurahan Sukaharja Kecamatan Delta Pawan Kabupaten Ketapang - Kalimantan Barat, \\ Kode Pos: 78813 \\ ${ }^{1}$ rizqia.lestika@gmail.com \\ ${ }^{2}$ noviindah.tilgmail.com
}

\begin{abstract}
Abstrak- Agar perangkat lunak e-Government dapat digunakan dalam menunjang kinerja organisasi dalam waktu yang relatif lama maka perlu dilakukan pemeliharaan perangkat lunak. Namun, berdasarkan hasil observasi pada organisasi perangkat daerah di Kabupaten Ketapang diketahui bahwa belum ada sebuah model atau standar yang dapat memberikan rekomendasi pemeliharaan secara objektif dan akurat. Penelitian ini mengusulkan sebuah model penilaian perangkat lunak untuk rekomendasi pemeliharaan dengan mengintegrasikan nilai bisnis dan nilai teknis. Identifikasi aset perangkat lunak, penilaian perangkat lunak, dan rekomendasi pemeliharaan adalah tiga tahap yang diusulkan dalam model ini. Kuesioner dengan skala Likert dan task analysis digunakan untuk menilai perangkat lunak berdasarkan nilai bisnis dan nilai teknis. Hasil validasi model melalui implementasi studi kasus di BKPSDM Ketapang diketahui bahwa model berhasil memberikan rekomendasi pemeliharaan untuk aplikasi SIMPAD adalah ordinary maintenance dan BAPERJAKAT adalah freeze.
\end{abstract}

Kata kunci - Model Penilaian, Nilai Bisnis dan Nilai Teknis, Rekomendasi Pemeliharaan, Evolusi Perangkat Lunak, EGovernment

\section{Pendahuluan}

Instruksi Presiden No.3 Tahun 2003, tentang kebijakan dan strategi nasional pengembangan aplikasi $e$ Government, menyatakan bahwa pemanfaatan teknologi informasi dalam proses pemerintahan bertujuan untuk meningkatkan efisiensi, efektivitas, transparansi dan akuntabilitas penyelenggaraan pemerintahan [1]. Dengan demikian, perangkat lunak e-Government seharusnya menjadi aset dan investasi bagi organisasi pemerintahan. Karena itu, perangkat lunak e-Government perlu dikelola dan dipelihara secara baik, sistematis, strategis, dan berkelanjutan.

Pengelolaan aset perangkat lunak yang baik dapat memperpanjang masa berlaku aset perangkat lunak sehingga memberikan keuntungan yang lebih bagi organisasi [2]. Namun, banyak organisasi dilaporkan gagal memperlakukan aset perangkat lunak yang mereka miliki secara baik, sehingga nilai investasinya tidak sepadan dengan nilai yang dikontribusikan oleh perangkat lunak tersebut [3].

Untuk menjaga nilai investasi tersebut, sebuah perangkat lunak perlu berevolusi [4]. Menurut Hukum Lehman I [4], pemeliharaan adalah proses yang tidak dapat dihindari, sebuah program yang digunakan di lingkungan dunia nyata perlu untuk berubah. Jika tidak, program tersebut akan menjadi tidak berguna. Pemeliharaan adalah penyesuaian (akomodasi) perubahan suatu perangkat lunak setelah disampaikan atau disebarkan kepada pengguna [5]. Perubahan perangkat lunak dapat berupa perubahan sederhana; seperti perbaikan kesalahan pengkodean dan perubahan yang lebih luas (kompleks); seperti perbaikan kesalahan desain, spesifikasi atau akomodasi kebutuhan baru [4]. Salah satu pertimbangan ketika melakukan pemeliharaan aset perangkat lunak e-Government adalah biaya yang dibutuhkan. Beberapa survei yang dilakukan menunjukkan bahwa biaya yang dikeluarkan ternyata lebih besar daripada biaya pengembangan aau pembangunan perangkat lunak itu sendiri [4].

Beberapa model penilaian perangkat lunak yang ditujukan untuk rekomendasi evolusinya sudah pernah dikembangkan oleh peneliti sebelumnya, antara lain; reengineering [6], re-architecture [7], Service Oriented Architecture (SOA) [8]. Dari penelitian tersebut dapat ditarik kesimpulan bahwa aspek bisnis dan teknis adalah dua aspek esensial dalam menilai aset perangkat lunak untuk rekomendasi pemeliharaannya. Selain itu, model penilaian perangkat lunak yang dikembangkan tersebut lebih ditujukan untuk perusahaan atau organisasi nonpemerintah yang bersifat profit-oriented [9][10][11][12][13]. Organisasi pemerintah, pada umumnya, menitikberatkan pada pelayanan publik dan bersifat non-profit. Dari hasil penelusuran, penelitian yang 
mengembangkan model penilaian aset perangkat lunak $e$ Government dan rekomendasi pemeliharaannya, khususnya dalam lingkup organisasi pemerintah daerah (OPD) di Indonesia belum banyak atau mungkin belum pernah dilakukan.

Dalam konteks penilaian dan pemeliharaan, suatu organisasi perlu mengetahui perangkat lunak mana saja yang masih dapat digunakan dan yang tidak sehingga organisasi dapat menentukan rencana ke depan terkait perangkat lunak baru yang dibutuhkan [14]. Informasi akurat dan obyektif hal ini akan mendukung efisiensi penggunaan anggaran untuk pengeluaran dan belanja pemerintah. Rekomendasi pemeliharaan yang diperoleh dari hasil penilaian tersebut dapat digunakan untuk menentukan keberlangsungan penggunaan perangkat lunak e-Government di masa mendatang. Oleh karena itu, penelitian ini yang akan mengembangkan suatu model penilaian aset perangkat lunak e-Government dan rekomendasi pemeliharaannya di lingkup Pemerintah Kabupaten Ketapang dianggap rasional dan penting dilakukan.

\section{LANDASAN TEORI}

\section{A. E-Government}

E-Government adalah wujud pemanfaatan teknologi informasi dan komunikasi untuk meningkatkan kegiatan dalam penyampaian layanan [15]. Pemanfaatan $e$ Government dapat melayani tujuan yang berbeda seperti pengiriman layanan pemerintah ke masyarakat yang lebih baik, meningkatkan interaksi dengan mitra bisnis dan industri, pemberdayaan masyarakat melalui akses informasi atau manajemen pemerintahan yang lebih efisien [16].

Ada tiga jenis umum sistem dan layanan $e$ Government [17], yaitu:

1) Government-to-Government $(G 2 G)$ : $\mathrm{G} 2 \mathrm{G}$ adalah sistem dan layanan yang memungkinkan pertukaran informasi dan komunikasi secara online antar departemen atau lembaga melalui basisdata yang terintegrasi.

2) Government-to-Citizen (G2C) : G2C adalah sistem dan layanan pemerintah ke masyarakat secara satu arah (layanan publik) yang memungkinkan pertukaran informasi dan komunikasi antara pemerintah dengan masyarakat.

3) Government-to-Business (G2B) : G2B adalah sistem dan layanan antara pemerintah dan kalangan bisnis melalui media komputer [18] di mana pemerintah menyediakan berbagai informasi yang dibutuhkan oleh kalangan bisnis untuk melakukan transaksi dengan pemerintah.

\section{B. Sistem Warisan}

Sistem warisan (legacy system) adalah sistem perangkat lunak lama yang sampai saat ini terus digunakan karena sistem tersebut kritikal bagi organisasi [5]. Menurut De Lucia, dkk., sistem warisan adalah sistem perangkat lunak kritikal yang dibangun pada masa lalu yang telah ada dan telah berubah pada waktu yang lama tanpa tindakan perbaikan yang sistematis [19]. Dari beberapa pengertian tersebut dapat disimpulkan bahwa sistem warisan adalah sistem perangkat lunak yang telah dibangun sebelumnya tetapi masih digunakan karena memiliki nilai kritikal bagi organisasi. Sebuah organisasi perlu menilai sistem warisan yang mereka miliki dan kemudian menentukan tindakan strategi yang paling tepat untuk perubahan sistem warisan [4].

\section{Nilai Bisnis}

Nilai Bisnis adalah nilai yang merepresentasikan pentingnya sebuah perangkat lunak bagi organisasi. Sumber informasi yang diperlukan untuk melakukan penilaian nilai bisnis sebuah perangkat lunak dapat diperoleh secara high level (penilaian menurut pendapat ahli) atau pun secara detailed level (penilaian yang dilakukan oleh analis bisnis) [6] atau dengan mempelajari dokumen bisnis organisasi [5].

\section{Nilai Teknis}

Nilai teknis adalah nilai yang menunjukkan seberapa baik kondisi dan kualitas dari suatu perangkat lunak untuk dapat diubah nantinya. Sumber informasi yang diperlukan untuk melakukan penilaian kualitas teknis dapat diperoleh dari staf ahli pemeliharaan yang berpengalaman atau mempelajari artefak sistem seperti kode sumber, dokumentasi sejarah perubahan atau dokumentasi pembangunan perangkat lunak. Penilaian nilai teknis sistem warisan dapat dilakukan melalui tiga pendekatan [5], yaitu:

1. Level sistem: melihat sistem sebagai black box.

2. Level komponen: melihat ke dalam sistem dan mengidentifikasi komponen proses. Penilaian ini cenderung untuk program aplikasi dan utilitas; termasuk dukungan program perangkat lunak untuk tugas seperti pencetakan dan penyortiran.

3. Level detail (constituent), hanya untuk komponen aplikasi perangkat lunak dengan menilai kinerja internal aplikasi perangkat lunak. Pada level ini, aplikasi perangkat lunak dinilai dalam hal program dan skema data.

\section{E. Pemeliharaan Perangkat Lunak (Software Maintenance)}

Menurut Warren [5] dan Sommerville [4] pemeliharaan adalah akomodasi perubahan setelah sistem disampaikan atau disebarkan. Pemeliharaan adalah kombinasi dari berbagai tindakan yang dilakukan untuk menjaga suatu barang atau memperbaikinya sampai pada suatu kondisi yang bisa diterima.

\section{Metode PENELITIAN}

Penelitian ini dilaksanakan pada Organisasi Perangkat Daerah (OPD) di lingkungan Pemerintah Kabupaten Ketapang dengan studi kasus di Badan Kepegawaian dan 
Pengembangan Sumber Daya Manusia (BKPSDM) Kabupaten Ketapang. Metode yang digunakan untuk mengembangkan model penilaian pada penelitian ini dilakukan dengan empat tahap seperti pada Gambar 1.

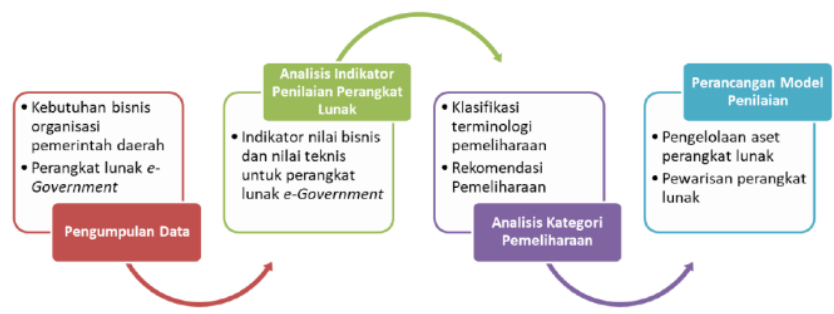

Gambar. 1 Metode penelitian

\section{A. Pengumpulan Data}

Pada tahap ini dilakukan penentuan faktor yang mempengaruhi nilai bisnis dan teknis berdasarkan karakteristik organisasi pemerintah daerah dan perangkat lunak e-Government dengan menganalisis kajian literatur terkait (lisensi, kontrak, dan dokumentasi, permasalahan, dan kebutuhan organisasi). Untuk memperoleh data terkait faktor tersebut secara lebih akurat dan komprehensif khusus untuk lingkup OPD di Kabupaten Ketapang (sampel), dilakukan dengan pengamatan (observasi) dan wawancara langsung serta penilaian empiris.

\section{B. Analisis Indikator Penilaian Perangkat Lunak}

Tahap ini adalah tahap analisis indikator nilai bisnis dan teknis secara kualitatif berdasarkan hasil-hasil penelitian terdahulu (literature review). Untuk mengetahui indikator yang paling signifikan mempengaruhi nilai bisnis dan teknis maka akan dilakukan pemetaan faktor terhadap variabel nilai bisnis/teknis menggunakan metrics mapping. Kemudian akan dikembangkan sejumlah pertanyaan untuk mengukur nilai bisnis dan teknis perangkat lunak menggunakan kuesioner yang dikembangakan dengan metode GQM (Goal Question Metric). Validitas isi dan konstruksi dari kuesioner GQM yang dikembangkan ini akan dilakukan oleh ahli. Nilai bisnis dan teknis perangkat lunak e-Government akan diklasifikasikan menjadi dua yaitu, tinggi (high) dan rendah (low).

\section{Analisis Kategori Pemeliharaan}

Pada tahap ini dilakukan analisis rekomendasi pemeliharaan perangkat lunak. Dilakukan klasifikasi pemeliharaan perangkat lunak berdasarkan terminologinya dengan menggunakan metrics mapping berdasarkan literature review. Rekomendasi pemeliharaan perangkat lunak mengacu pada model Quadrant Mapping.

\section{Perancangan Model Penilaian}

Setalah tahap analisis dilakukan maka berdasarkan hasil analisis dilakukan perancangan model penilaian aset perangkat lunak. Dari hasil analisis kualitatif penilaian perangkat lunak dan rekomendasi pemeliharaannya akan dikembangkan model penilaian dengan mengintegrasikan konsep pengelolaan aset dan pewarisan perangkat lunak dengan mengacu pada model Quadrant Mapping yang menggunakan Metrics Recommendation.

\section{HASIL PENELITIAN}

Model penilaian perangkat lunak e-Government untuk rekomendasi pemeliharaan dapat dilihat pada Gambar. 2. Untuk menentukan rekomendasi pemeliharaan aset perangkat lunak e-Government ada tiga tahapan yang menjadi bagian penting yaitu, tahapan pengelolaan aset perangkat lunak di organisasi, tahapan penilaian aset perangkat lunak dan tahapan rekomendasi.

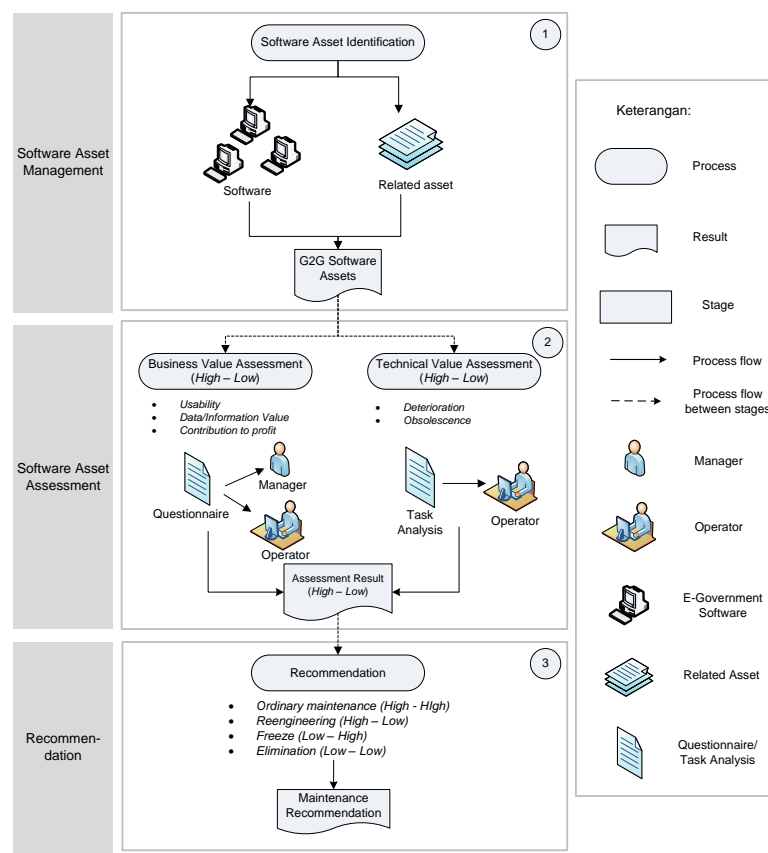

Gambar. 2 Model penilaian untuk rekomendasi pemeliharaan

Masing-masing dari tahapan tersebut menghasilkan informasi yang dibutuhkan untuk rekomendasi pemeliharaan aset perangkat lunak warisan seperti yang akan dijelaskan berikut ini:

1) Tahap pengelolaan aset perangkat lunak: Pada tahap ini dihasilkan informasi aset perangkat lunak $e$ Government beserta aset lain yang berhubungan dengan perangkat lunak. Aset perangkat lunak e-Government yang diidentifikasi kemudian diklasifikasi berdasarkan jenis layanannya, yaitu G2G, G2C, dan G2B. Penilaian aset perangkat lunak e-Government pada penelitian ini fokus untuk layanan $\mathrm{G} 2 \mathrm{G}$.

TABEL I

ATRIBUT INFORMASI PERANGKAT LUNAK

\begin{tabular}{|c|l|l|}
\hline No. & \multicolumn{1}{|c|}{$\begin{array}{c}\text { Atribut } \\
\text { Informasi }\end{array}$} & \multicolumn{1}{c|}{ Deskripsi } \\
\hline 1 & $\begin{array}{l}\text { Nama perangkat } \\
\text { lunak }\end{array}$ & $\begin{array}{l}\text { Informasi identitas berdasarkan nama } \\
\text { perangkat lunak }\end{array}$ \\
\hline 2 & $\begin{array}{l}\text { Wali/Pemilik } \\
\text { perangkat lunak }\end{array}$ & $\begin{array}{l}\text { Informasi identitas organisasi perangkat } \\
\text { daerah yang bertanggung jawab atas }\end{array}$ \\
\hline
\end{tabular}




\begin{tabular}{|c|l|l|}
\hline No. & \multicolumn{1}{|c|}{$\begin{array}{c}\text { Atribut } \\
\text { Informasi }\end{array}$} & \multicolumn{1}{c|}{ Deskripsi } \\
\hline & & perangkat lunak \\
\hline 3 & Lokasi & $\begin{array}{l}\text { Informasi lokasi bagian/sub bagian yang } \\
\text { menggunakan perangkat lunak }\end{array}$ \\
\hline 4 & Status & $\begin{array}{l}\text { Informasi status penggunaan perangkat } \\
\text { lunak }\end{array}$ \\
\hline 5 & Versi & Informasi versi perangkat lunak \\
\hline 6 & Vendor & $\begin{array}{l}\text { Informasi identitas vendor yang } \\
\text { mengembangkan perangkat lunak }\end{array}$ \\
\hline 7 & Dokumentasi & $\begin{array}{l}\text { Informasi kelengkapan dokumentasi } \\
\text { pendukung }\end{array}$ \\
\hline 8 & Informasi & $\begin{array}{l}\text { Informasi kegiatan pemeliharaan atau } \\
\text { perubahan yang dilakukan }\end{array}$ \\
\hline
\end{tabular}

2) Tahap penilaian aset perangkat lunak: Kumpulan proses pada tahap ini menghasilkan penilaian aset perangkat lunak e-Government berdasarkan nilai bisnis dan nilai teknis yang diperlukan untuk menentukan rekomendasi pemeliharaannya.

Penilaian ini didasarkan pada dua aspek penilaian yaitu, nilai bisnis dan nilai teknis.

Untuk menilai nilai bisnis, ada tiga variabel yang diukur yaitu, utility, data/information value, dan contribution to profit.

- Utility (kegunaan), merepresentasikan pentingnya penggunaan perangkat lunak dalam mendukung proses bisnis organisasi.

- Data/information value (nilai data/informasi), merepresentasikan relevansi data atau informasi yang dikelola oleh perangkat lunak untuk proses bisnis organisasi.

- Contribution to profit (kontribusi keuntungan), merepresentasikan efek keuntungan dari penggunaan perangkat lunak baik secara individu atau organisasi secara keseluruhan.

Deskripsi detail dari variable dan indikator penilaian nilai bisnis dapat dilihat pada Tabel 2 .

TABEL III

VARIABEL DAN INDIKATOR NILAI BISNIS

\begin{tabular}{|c|c|c|c|}
\hline No. & Variabel & Indikator & Tujuan \\
\hline \multirow[t]{3}{*}{1} & \multirow[t]{3}{*}{$\begin{array}{l}\text { Kegunaan } \\
\text { (Utility) }\end{array}$} & Efektivitas & $\begin{array}{l}\text { Menilai efektivitas } \\
\text { aplikasi dalam } \\
\text { menjalankan tugas } \\
\text { kerja dan } \\
\text { mendukung } \\
\text { pencapaian tujuan } \\
\text { organisasi. }\end{array}$ \\
\hline & & Efisiensi & $\begin{array}{l}\text { Menilai efisiensi } \\
\text { aplikasi dalam } \\
\text { menjalankan tugas } \\
\text { kerja. }\end{array}$ \\
\hline & & $\begin{array}{l}\text { Frekuensi } \\
\text { penggunaan }\end{array}$ & $\begin{array}{l}\text { Menilai frekuensi } \\
\text { penggunaan aplikasi } \\
\text { dalam mendukung } \\
\text { tugas kerja. }\end{array}$ \\
\hline \multirow[t]{2}{*}{2} & \multirow[t]{2}{*}{$\begin{array}{l}\text { Nilai } \\
\text { Data/Informasi } \\
\text { (Data/informatio } \\
n \text { value) }\end{array}$} & Akurasi & $\begin{array}{l}\text { Menilai keakuratan } \\
\text { dari data/informasi } \\
\text { yang dikelola oleh } \\
\text { aplikasi. }\end{array}$ \\
\hline & & Kelengkapan & Menilai \\
\hline
\end{tabular}

\begin{tabular}{|c|c|c|c|}
\hline No. & Variabel & Indikator & Tujuan \\
\hline & & & $\begin{array}{l}\text { kelengkapan dari } \\
\text { data/informasi yang } \\
\text { dikelola oleh } \\
\text { aplikasi. }\end{array}$ \\
\hline & & Ketepatan waktu & $\begin{array}{l}\text { Menilai ketepatan } \\
\text { waktu dari } \\
\text { perbaruan } \\
\text { data/informasi yang } \\
\text { dikelola oleh } \\
\text { aplikasi. }\end{array}$ \\
\hline & & Integrasi & $\begin{array}{l}\text { Menilai kebutuhan } \\
\text { data/informasi yang } \\
\text { dikelola oleh } \\
\text { aplikasi, baik secara } \\
\text { internal maupun } \\
\text { eksternal. }\end{array}$ \\
\hline & & Dependensi & $\begin{array}{l}\text { Menilai } \\
\text { ketergantungan } \\
\text { organisasi terhadap } \\
\text { data/informasi yang } \\
\text { dikelola aplikasi, } \\
\text { baik secara internal } \\
\text { maupun eksternal. }\end{array}$ \\
\hline 3 & $\begin{array}{l}\text { Kontribusi } \\
\text { keuntungan } \\
\text { (Contribution to } \\
\text { profit) }\end{array}$ & $\begin{array}{l}\text { Dampak } \\
\text { keuntungan: } \\
\text { a. Produktivitas } \\
\text { b. Efektivitas } \\
\text { c. Efisiensi }\end{array}$ & $\begin{array}{l}\text { Menilai dampak } \\
\text { pemanfaatan dari } \\
\text { implementasi } \\
\text { aplikasi baik oleh } \\
\text { individu maupun } \\
\text { organisasi yang } \\
\text { dilihat dari } \\
\text { peningkatan } \\
\text { produktivitas } \\
\text { efektivitas dan } \\
\text { efisiensi kerja. }\end{array}$ \\
\hline
\end{tabular}

Untuk menilai nilai teknis dari perangkat lunak, ada dua variabel yang akan diukur yaitu, deterioration dan obsolescence.

1) Deterioration (penurunan), merepresentasikan penurunan fungsionalitas perangkat lunak karena kegagalan dalam memenuhi perubahan kebutuhan. Pengukurannya dilakukan dengan metode blackbox untuk melihat fungsionalitas perangkat lunak.

2) Obsolescence (keusangan), merepresentasikan keusangan perangkat lunak (umur).

Deskripsi detail dari variabel dan indikator penilaian nilai bisnis dapat dilihat pada Tabel 3 .

TABEL III

VARIABEL DAN INDIKATOR NILAI TEKNIS

\begin{tabular}{|c|c|c|c|}
\hline $\begin{array}{l}\mathbf{N} \\
\mathbf{0}\end{array}$ & $\begin{array}{c}\text { Variabel } \\
\text { Nilai Teknis }\end{array}$ & Indikator & Tujuan \\
\hline \multirow[t]{3}{*}{1} & \multirow[t]{3}{*}{$\begin{array}{l}\text { Penurunan } \\
\text { (deterioration) }\end{array}$} & $\begin{array}{l}\text { Frekuensi } \\
\text { terjadinya } \\
\text { kesalahan }\end{array}$ & $\begin{array}{l}\text { Mengukur frekuensi } \\
\text { terjadinya } \text { error pada } \\
\text { perangkat lunak. }\end{array}$ \\
\hline & & $\begin{array}{l}\text { Penyelesaian } \\
\text { tugas }\end{array}$ & $\begin{array}{l}\text { Mengukur tugas yang } \\
\text { dapat diselesaikan } \\
\text { dengan benar oleh } \\
\text { perangkat lunak. }\end{array}$ \\
\hline & & Waktu respon & $\begin{array}{l}\text { Mengukur berapa } \\
\text { lama waktu respon } \\
\text { yang diperlukan } \\
\text { perangkat lunak pada } \\
\text { saat merespon suatu } \\
\text { tindakan. }\end{array}$ \\
\hline
\end{tabular}




\begin{tabular}{|c|l|l|l|}
\hline $\begin{array}{c}\text { N } \\
\text { o }\end{array}$ & $\begin{array}{c}\text { Variabel } \\
\text { Nilai Teknis }\end{array}$ & \multicolumn{1}{|c|}{ Indikator } & \multicolumn{1}{c|}{ Tujuan } \\
\hline 2 & $\begin{array}{l}\text { Keusangan } \\
\text { (obsolescence) }\end{array}$ & Umur (age) & $\begin{array}{l}\text { Mengukur umur } \\
\text { perangkat lunak. }\end{array}$ \\
\cline { 3 - 4 } & & $\begin{array}{l}\text { Dokumentasi } \\
\text { (documentation) }\end{array}$ & $\begin{array}{l}\text { Mengetahui } \\
\text { dokumentasi } \\
\text { pendukung yang } \\
\text { dimiliki oleh } \\
\text { perangkat lunak. }\end{array}$ \\
\cline { 3 - 4 } & & $\begin{array}{l}\text { Mengetahui bahasa } \\
\text { pemrograman yang } \\
\text { digunakan untuk } \\
\text { mengembangkan } \\
\text { perangkat lunak. }\end{array}$ \\
\cline { 3 - 4 } & $\begin{array}{l}\text { Bahasa } \\
\text { pemrograman } \\
\text { (programming } \\
\text { language) }\end{array}$ & \\
\hline
\end{tabular}

3) Tahap rekomendasi : Tahap ini bertujuan untuk menghasilkan rekomendasi pemeliharaan aset perangkat lunak e-Government berdasarkan hasil penilaian aset perangkat lunak dari proses sebelumnya. Untuk menentukan rekomendasi pemeliharaannya, dilakukan integrasi antara hasil penilaian nilai bisnis dan nilai teknis. Pada tahap ini akan dihasilkan informasi aset perangkat lunak e-Government yang dapat diwariskan.

TABEL IV

MATRIKS REKOMENDASI PEMELIHARAAN

\begin{tabular}{|c|c|c|c|}
\hline $\begin{array}{c}\text { Nilai } \\
\text { Bisnis }\end{array}$ & $\begin{array}{c}\text { Nilai } \\
\text { Teknis }\end{array}$ & $\begin{array}{c}\text { Rekomendasi } \\
\text { Pemeliharaan }\end{array}$ & Pewarisan \\
\hline Tinggi & Tinggi & $\begin{array}{c}\text { Ordinary } \\
\text { maintenance }\end{array}$ & $\begin{array}{c}\text { Kandidat kuat } \\
\text { untuk } \\
\text { diwariskan }\end{array}$ \\
\hline Tinggi & Rendah & Reengineering & Diwariskan \\
\hline Rendah & Tinggi & Freeze & $\begin{array}{c}\text { Kandidat } \\
\text { lemah untuk } \\
\text { diwariskan }\end{array}$ \\
\hline Rendah & Rendah & Eliminantion & $\begin{array}{c}\text { Tidak dapat } \\
\text { diwariskan }\end{array}$ \\
\hline
\end{tabular}

Untuk memvalidasi model ini, dilakukan implementasi model pada sebuah organisasi perangkat daerah sebagai studi kasus yaitu, BKPSDM Ketapang. SIMPAD (Sistem Informasi Pengelolaan Arsip Digital) dan BAPERJAKAT (Badan Pertimbangan Jabatan dan Kepangkatan) adalah dua perangkat lunak e-Government yang dinilai oleh model. Hasil penilaian nilai bisnis dan nilai teknis dapat dilihat pada Tabel V dan Tabel VI.

TABEL V

HASIL PENILAIAN NILAI BISNIS

\begin{tabular}{|c|c|c|c|}
\hline \multirow[t]{2}{*}{ Variabel } & \multirow[t]{2}{*}{ Indikator } & \multicolumn{2}{|c|}{ Nilai } \\
\hline & & SIMPAD & $\begin{array}{l}\text { BAPER } \\
\text { JAKAT }\end{array}$ \\
\hline \multirow[t]{7}{*}{ Kegunaan } & \multirow[t]{3}{*}{ Efektivitas } & 4 & 3 \\
\hline & & 4 & 3 \\
\hline & & 4 & 3 \\
\hline & \multirow[t]{2}{*}{ Efisiensi } & 4 & 3 \\
\hline & & 4 & 4 \\
\hline & $\begin{array}{l}\text { Frekuensi } \\
\text { penggunaan }\end{array}$ & 4 & 3 \\
\hline & & 3 & 3 \\
\hline Nilai & Akurasi & 4 & 3 \\
\hline
\end{tabular}

\begin{tabular}{|c|c|c|c|}
\hline \multirow{10}{*}{ Data/Informasi } & \multirow[t]{2}{*}{ Indikator } & \multicolumn{2}{|c|}{ Nilai } \\
\hline & & SIMPAD & $\begin{array}{l}\text { BAPER } \\
\text { JAKAT }\end{array}$ \\
\hline & Kelengkapan & 4 & 3 \\
\hline & \multirow{2}{*}{$\begin{array}{l}\text { Ketepatan } \\
\text { waktu }\end{array}$} & 4 & 3 \\
\hline & & 4 & 1 \\
\hline & \multirow[t]{2}{*}{ Integrasi } & 3 & 4 \\
\hline & & 3 & 2 \\
\hline & \multirow[t]{3}{*}{ Dependensi } & 1 & 1 \\
\hline & & 4 & 1 \\
\hline & & 3 & 2 \\
\hline \multirow[t]{8}{*}{$\begin{array}{l}\text { Kontribusi } \\
\text { keuntungan }\end{array}$} & $\begin{array}{l}\text { Dampak } \\
\text { keuntungan }\end{array}$ & & \\
\hline & \multirow{3}{*}{$\begin{array}{l}\text { a. } \\
\text { Produktivitas }\end{array}$} & 3 & 3 \\
\hline & & 3 & 3 \\
\hline & & 4 & 3 \\
\hline & \multirow[t]{2}{*}{ b. Efektivitas } & 4 & 3 \\
\hline & & 4 & 3 \\
\hline & \multirow[t]{2}{*}{ c. Efisiensi } & 4 & 4 \\
\hline & & 4 & 4 \\
\hline \multicolumn{2}{|l|}{ Jumlah } & 81 & 65 \\
\hline \multicolumn{2}{|l|}{ Rata-rata } & 3.52 & 2.82 \\
\hline \multicolumn{2}{|l|}{ Kualifikasi } & Tinggi & Rendah \\
\hline
\end{tabular}

TABEL VI

HASIl PENILAIAN NILAI TEKNIS

\begin{tabular}{|c|c|c|c|c|}
\hline \multirow{2}{*}{$\begin{array}{c}\text { No } \\
\text {. }\end{array}$} & \multirow[t]{2}{*}{ Variabel } & \multirow[t]{2}{*}{ Indikator } & \multicolumn{2}{|c|}{ Nilai } \\
\hline & & & SIMPAD & $\begin{array}{l}\text { BAPER } \\
\text { JAKAT }\end{array}$ \\
\hline \multirow[t]{3}{*}{1} & \multirow[t]{3}{*}{ Penurunan } & $\begin{array}{l}\text { Frekuensi } \\
\text { terjadinya } \\
\text { kesalahan }\end{array}$ & 4 & 4 \\
\hline & & $\begin{array}{l}\text { Penyelesaian } \\
\text { tugas }\end{array}$ & 4 & 4 \\
\hline & & Waktu respon & 4 & 4 \\
\hline \multirow[t]{3}{*}{2} & \multirow[t]{3}{*}{ Keusangan } & Umur & 4 & 3 \\
\hline & & Dokumentasi & 2 & 1 \\
\hline & & $\begin{array}{l}\text { Bahasa } \\
\text { pemrograman }\end{array}$ & 3 & 3 \\
\hline \multicolumn{3}{|c|}{ Jumlah } & 21 & 19 \\
\hline \multicolumn{3}{|c|}{ Rata-rata } & 3.5 & 3.17 \\
\hline \multicolumn{3}{|c|}{ Kualifikasi } & Tinggi & Tinggi \\
\hline
\end{tabular}

Dari hasil penilaian nilai bisnis dan nilai teknis diketahui bahwa nilai bisnis untuk perangkat lunak SIMPAD berkualifikasi tinggi (rata-rata berada di antara 3.00 - 4.00) dan BAPERJAKAT berkualifikasi rendah (rata-rata berada di antara 1.00 - 2.99) dan untuk nilai teknis dari kedua perangkat lunak tersebut berkualifikasi tinggi (rata-rata berada di antara $3.00-4.00$ ). Oleh karena itu, berdasarkan matrik rekomendasi pemeliharaan maka rekomendasi pemeliharaan untuk perangkat lunak SIMPAD adalah ordinary maintenance dan BAPERJAKAT adalah freeze.

\section{KESIMPULAN}

Penelitian ini menghasilkan model penilaian aset perangkat lunak untuk rekomendasi pemeliharaan berdasarkan dua aspek penilaian yaitu: nilai bisnis dan nilai teknis. Nilai bisnis perangkat lunak e-Government 
dipengaruhi oleh variabel kegunaan (efektivitas, efisiensi, frekuensi penggunaan), nilai data/informasi (akurasi, kelengkapan, ketepatan waktu, integrasi dan depedensi) dan kontribusi keuntungan (produktivitas,efektivitas dan efisiensi). Nilai teknis perangkat lunak e-Government dipengaruhi oleh variabel penurunan (frekuensi terjadinya kesalahan, penyelesaian tugas dan waktu respon) dan keusangan (umur, dokumentasi dan bahasa pemrograman). Rekomendasi pemeliharaan aset perangkat lunak e-Government diberikan dengan mengintegrasikan hasil penilaian aset perangkat lunak e-Government ditinjau dari kualifikasi nilai bisnis (tinggi-rendah) dan nilai teknis (tinggi-rendah). Berdasarkan implementasi model di BKPSDM Ketapang, sebagai studi kasus penelitian ini, model ini dapat digunakan untuk menilai dan memberikan rekomendasi pemeliharaan perangkat lunak e-Government.

\section{UCAPAN TERIMA KASIH}

Terima kasih kepada pemangku kepentingan, pegawai dan operator di Badan Kepegawaian dan Pengembangan Sumber Daya Manusia (BKPSDM) Kabupaten Ketapang atas bantuan dan kerja samanya.

\section{REFERENSI}

[1] Inpres No.3. (2003). Dipetik January 28, 2016, dari jatim.kemenag.go.id: http://jatim.kemenag.go.id/file/file/PP/xvrb1451984221.pdf

[2] Sinha, A., \& Lahiri, R. (2007). Complete IT Solution for Enterprise Asset Management (EAM) in Indian Power Utility Business. Universitas Power Engineering Conference (UPEC) 42nd International, 645-650.

[3] Microsoft. (2006). More and More Companies are Reaping the Rewards of IT and Software Asset Management: What do they know that you don't?. Dipetik April 18, 2015, dari https://www.microsoft.com/en-us/sam/

[4] Sommerville, I. (2011). Software Engineering 9th edition. United States of America: Addison-Wesley.

[5] Warren, I. (1999). The Renaissance of Legacy System Method Support for Software Evolution. London: Springer.

[6] Ransom, J., Sommerville, I., \& Warren, I. (1998). A Method for Assessing Legacy Systems for Evolution. Software Maintenance and Reengineering, 1998. Proceedings of the Second Euromicro Conference, 128-134.

[7] Alkazemi, B. Y., Nour, M. K., \& Meelud, A. Q. (2013). Towards a Framework to Assess Legacy Systems. 2013 IEEE International Conference on Systems, Man, and Cybernetics, 924-928.
[8] Santana, H. E., \& Carneiro, G. d. (2014). A Decision Process to Migrate Legacy Systems to SOA. International Conference on Information Technology.

[9] Wahyuni, F., \& Angraini. (2015). Evaluasi Penerapan EGovernment Pada Dinas Komunikasi dan Informatika Provinsi Riau Menggunakan Pendekatan Metode PeGI. Rekayasa dan Manajemen Sistem Informasi, 39-43.

[10] Hakim, A., Saragih, H., \& Suharto, A. (2014). Evaluasi Tata Kelola Teknologi Informasi dengan Framework COBIT. 5 di Kementrian ESDM (Studi Kasus pada Pusat Data dan Teknologi Informasi ESDM). Journal of Information Systems, Volume 10, Issue $2,105-117$

[11] Purbawangsa, I. N., Darwiyanto, E., \& W., K. R. (2014). Evaluasi Sistem E-Government Kota Denpasar Menggunakan Framework COBIT 5 pada Domain Monitor, Evaluate, and Assess (MEA). 19.

[12] Fitriansyah, A., Budiarto, H., \& Santoso, J. (2013). Metode Pemeringkatan E-Government Indonesia (PeGI) untuk Audit Tata Kelola Teknologi Informasi. Seminar Nasional Sistem Informasi Indonesia, 10-20.

[13] Hernikawati, D. (2013). Kajian Implementasi E-Government Tingkat Provinsi Di Indonesia. Universitas Indonesia.

[14] Canavan, R. (2012). ISO 19770-1: SAM Process Guidance A Kick-start to your SAM Programme. Dipetik April 29, 2016, dari Google Buku: https://books.google.co.id/books

[15] Kumar, R., \& Best, M. (2006). Impact and Sustainability of $E$ Government Services in Develoing Countries: Lessons Learned from Tamil Nadu, India. Information Society, 1-12.

[16] Badri, M. A., \& Alshare, K. (2008). A Path Analytic Model and Measurement of Tthe Business Value of E-Government: An International Perspective. International Journal of Information Management , 524-535.

[17] Dong, X., Xiong, L., \& Han, S. (2010). How adoption is G2B model E-Government? Evidence from Xi'an. 2010 International Conference on Management and Service Science.

[18] Joseph, R. C. (2009). Government-To-Business (G2B) Perspectives In E-Government. Northeast Decision Sciences Institute Annual Conference (hal. 1). Cambridge: Northeast Decision Sciences Institute.

[19] DeLucia, A., \& dkk. (2001). A Decisional Framework for Legacy System Management. IEEE International Conference on Software Maintenance, 642-651.

[20] Alkazemi, B. Y., Nour, M. K., \& Meelud, A. Q. (2013). Towards a Framework to Assess Legacy Systems. 2013 IEEE International Conference on Systems, Man, and Cybernetics, 924-928.

[21] Corder, A. (1996). Teknik Manajemen Pemeliharaan. Jakarta: Erlangga.

[22] Cimitile, A., Fasolino, A. R., \& Lanubile, F. (2001). Legacy System Assessment to Support Decision Making. IEEE Workshop on Empirical Studies of Software Maintenance, 145-150 